\title{
CHILD LABOR AND THE PUBLIC SCHOOLS
}

\author{
By Samuel McCune Lindsay, Ph.D., \\ Secretary of the National Child Labor Committee.
}

The restriction or the abolition of child labor will impose new duties and open up new opportunities for the public school everywhere. What is the cost of child labor, not to the children in terms of stunted bodies and dwarfed minds, but to society, in terms of racial and industrial deterioration? We frequently ask that question and usually answer it by coming to a firm conviction that it does not pay. It is not worth the price we pay for it. It is equally necessary that we should ask ourselves what will it cost society to restrict or to abolish child labor. This cost will be measured largely in terms of the cost of additional schools, better and more varied training, including, of course, trade schools, and some additional relief for poverty.

Education is fundamental in the normal evolution of society and of the state. Therefore the public school should be as comprehensive as the needs of the state itself, and the supreme object of public responsibility. We are still far from a realization of this axiomatic truth in any part of these United States of to-day, though we seem to have set our faces in that direction even in the poorest and most backward sections of our country. The great Social Education Congress recently held in Boston is a proof of this fact. Not many years ago, in another section of our country, only a few hundred miles from Boston, I heard emphatically defended from a public platform another doctrine, namely, that the state has no responsibility nor concern for education beyond furnishing the mere rudiments to pauper children, and that the proper function of the public school is to be in reality nothing more than a pauper school. While such doctrine would meet with little acceptance in any community now, it is well to recall the fact that it is less than a century since we established anywhere a system of public schools based 
upon a radically different idea. Many of us still act as though we were satisfied that the state had discharged its full responsibility when it has taught the spelling book to only a fraction-even though a large fraction-of its children. Education carried beyond the spelling book becomes increasingly expensive and the taxpayer's voice and vote increasingly insistent that we do not go too far.

It is to be earnestly desired that, in every public gathering like this, where the permanent welfare of the child is an object of concern and discussion, we ask how far is far enough. Let us ask this question in a wholly disinterested manner, having taken note not only of the interest of the taxpayer, important as that is, but also of the equally important interests of the state, and of all her children who constitute her greatest asset, even when measured in terms of their economic value. We shall be able to answer the question: How far must the state go in the use of its power and revenues for the promotion of public education, for our own day and generation, if we study carefully the new duties and responsibilities which the Zeitgeist imposes.

I shall now endeavor to point out two or three ways in which some new expansive forces are acting on the public school:

(I) A new and more intense social spirit pervades the republic. This is an inevitable consequence of improved communication, a result of the development in transportation by land and water, the telegraph, telephone, newspaper, the increase in wealth and interchange of products. The individual, family, town, city or state can no longer live an isolated life, but is almost instantly affected by the prosperity, health and wealth, or by the poverty, disease, ignorance and vice of other groups with whom they are in close relation, but over whose acts they have only an indirect control. It is no longer possible within the bounds of our western civilization to keep social opportunities at radically different levels, to have a part of the population densely ignorant and inefficient and to guarantee the advantages of culture and efficiency to another part. Inter-communication, which is the very life of modern commerce, is the siphon that connects the various sections of our country which provide unequal opportunities and educational advantages which must henceforth seek a common level or some basis of equalization.

(2) All the children of the republic are equally objects of its concern. We can no longer fail to ponder seriously the facts that 
show I0.7 per cent of the population over ten years of age illiterate, which must mean that it has not been touched at all by the school, public or private; that show only 50.5 per cent of the population five to twenty years of age attending school; that show only 79.8 per cent of the population ten to fourteen years of age attending school in those years which should be so sacredly guarded as the golden educational and preparational period in the life of every boy and girl; facts that show that one in every six children ten to sixteen years of age is engaged in some gainful occupation, trying to earn his or her. own bread, or contribute to the support of a family; and finally the fact that at least 500,000 children of these ages are engaged in specially hazardous occupations which are quite likely to sap their nervous energy, stunt their physical growth, blight their minds, destroy their moral fiber and fit them for the social scrap heap before they have ever had any real chance to respond to stimuli that probably would make of most of them valuable members of society. The public school has not fulfilled its mission until it can answer for the whereabouts of every child within its jurisdiction and guarantee to the state that all its children are being properly educated, their energies properly safeguarded, until they reach the age of full discretion, whether at work, study or play-and all three of these factors should enter into the growth of every child.

(3) The demand for efficiency is a demand for training. Not only must all the children of the nation be reached by the school, not only is it the legitimate concern of the people of Georgia to see that the children of Massachusetts are being reached by the public school, and vice versa, but also must we see that these children are raised at least to a certain minimum level of efficiency in doing the things at which they are destined to spend the major portion of their lives, and through the doing of which they in turn will support themselves and the state. There is no place in a democracy for public education that is not vocational in addition to being cultural. Are American standards of humanity, of political sagacity, and of common business shrewdness sufficiently high? Will they protect childhood from the greed of employers who are grappling with the difficulties of a short labor supply and high wages, and who would draft the child into their service because he can be had easily and for small wages? Will they protect children from the greed of vicious parents who would rid themselves of the duties and respon- 
sibility of parenthood, or from the indifference of ignorant parents to the sacrifice of their children, or from the dire necessity of the poor parent who is driven by hunger to offer his child unto Moloch? If we are prepared for legislation forbidding child labor under fourteen years of age in all occupations, and under sixteen years of age at night work and in specially dangerous occupations, we must also be prepared to pay the cost of this new social standard. The cost means more schools and better schools, schools that will do all in the way of trade education and more for the child than he can receive from any factory, mine or workshop, and finally make provision for his physical necessities sufficient to enable him to improve the opportunities in all cases where the poverty of parent or guardian makes this impossible. The state now furnishes a school room, desks, pencils, books and materials, irrespective of the child's ability to pay for them, because in this way, and only by so doing, as experience proves, do we get the desired community result from the school as a whole. It is an equally important factor in the ability of the pupil to do a good day's work at school that he come to school properly fed and clothed, and we must be prepared to provide in some way for the physical needs of underfed and improperly clothed school children if we expect our schools to be really efficient. Whether we do this from the public school budget or not, as we now buy text-books and maps, is not half so important a question as the fact that the school is now committed of necessity to seeing that it is done. The public may decide that it prefers to rely upon private agencies or philanthropy to provide the means, nevertheless, in seeing that it is done, the school is brought into closer organic relations to the life of the community and the vital interests of the child are enhanced.

(4) The public school is an administrative department of government. The President's Cabinet needs a Secretary of Education even more than a Secretary of War-and the present versatile, high-minded and able-bodied occupant of the latter post could most worthily hold the educational portfolio. Every Governor needs a Superintendent of Public Instruction as a more active member of his council than a Secretary of the Commonwealth can possibly be, and the Mayor of every town and city needs the Superintendent of Schools as a right-hand adviser more than he needs a Police Commissioner. Our public schools must be prepared to enlarge their 
administrative duties if they expect to get a larger share of the public revenues so urgently needed to carry on their work. Already in large cities the tenement house inspectors, the health officials and sanitary inspectors, the factory inspectors and many other public officials depend increasingly on school teachers and school officials for aid in their work, because the teachers and school officials are in closer and more vital relation to the homes of the people than any other body of public officials. It is a short-sighted policy for any school official to resist these new demands on his already overtaxed fund of energy, because by responding to them he will find the quickest relief which will come through public appreciation of the great burdens he is now carrying and the willingness to give him more adequate support. Unfortunately, few departments of administrative government are in general so poorly organized on the business side as our departments of public education. In none is it more difficult to get satisfactory reports of what is being done, enlightening statistics that enable one to measure results or to calculate the relative cost of work done and that which is left undone because of lack of means. All this works to the disadvantage of the school and the teacher, because the public at large is more sympathetically inclined to support and develop public education than any other department of social work, if its needs can be properly presented for public discussion. It is safe to say that there is no city system of schools in the United States that could not legitimately absorb within the next ten years the total sum of money now raised and that will be raised at the present tax rate for all public expenses in that city each year during the next ten years, and that the legitimacy of this demand would be admitted and the means found through new sources of revenue, if the facts were placed before the public by the school officials, who should know them, and in a way to be clearly understood by the public and the organized agencies now doing the social work of these several localities. What I have just said of our city system of schools, I believe, would hold equally good for many smaller town and country districts.

(5) The public school, next to the parent, is the proper guardian of the rights of childhood. It must in all cases co-operate with the parent in the performance of this duty, and where the parent is wanting or unfit, as is sometimes the case, the school, as the chief agent of the state for this purpose, becomes the sole executor. In 
our present-day industrial system, the rights of childhood are being invaded and nullified in no more important and unnecessary manner than in the widespread prevalence of child labor. Why have schools at all, and why pass compulsory education laws, if at the same time we permit the employment of children of school age and thereby create conditions which tempt employers, parents and children alike to make both schools and laws of no avail. The public school should, therefore, be the leader of the forces militantly and wisely engaged in the efforts to abolish child labor and regulate the abuses of the rights of childhood. 